\title{
Effect of dietary bovine lactoferrin on lipid peroxidation and activities, and mRNA levels of antioxidant enzymes of piglets*
}

\author{
C.L. Xu' ${ }^{1}$, Y.Z. Wang ${ }^{1,3}$, J.X. Liu ${ }^{2,3}$, G.J. Yao ${ }^{1}$ and J. Feng ${ }^{1}$ \\ ${ }^{1}$ Key Laboratory of Molecular Animal Nutrition of Ministry of Education, \\ Feed Science Institute, Zhejiang University \\ No.164 Qiutao North Road, Hangzhou, 310029, P.R. China \\ ${ }^{2}$ Institute of Dairy Science and Industry, Zhejiang University \\ Hangzhou, 310029, P.R. China
}

(Received 29 May 2006; revised version 28 August 2006; accepted 6 November 2006)

\begin{abstract}
The experiment was conducted to evaluate effect of dietary bovine lactoferrin (bLF) on lipid peroxidation and activities as well as mRNA levels of antioxidant enzymes of piglets. Duroc $\times$ Landrace $\times$ Yorkshire crossbred female piglets $(n=120,35$ days of age, liveweight $9.70 \pm 0.71 \mathrm{~kg}$ ) were fed a diet containing 0,1250 , or $2500 \mathrm{mg} / \mathrm{kg}$ bLF for 30 days. After completion of the feeding experiment, twelve female piglets with 4 animals in each treatment were randomly selected to determine malondialdehyde (MDA) and total antioxidant capacity (TAOC) levelsczinc-superoxide dismutase (CuZnSOD), glutathione perioxidase (GPx), catalase (CAT) activities in serum and liver, and CuZnSOD, GPx and CAT mRNA levels in liver. Results showed that piglets treated with $2500 \mathrm{mg} / \mathrm{kg}$ bLF significantly increased $(\mathrm{P}<0.05)$ TAOC levels, the activities of GPx, CuZnSOD and CAT, and mRNA levels of CuZnSOD, GPx and CAT, and decreased $(\mathrm{P}<0.05)$ the contents of MDA as compared with control. Supplementation with $1250 \mathrm{mg} / \mathrm{kg}$ bLF also increased $(\mathrm{P}<0.05)$ the activities of CuZnSOD, GPx and CAT and mRNA levels of GPx and CAT, and decreased $(\mathrm{P}<0.05)$ the contents of MDA as compared with control, but the effect was not better than that of dietary addition of $2500 \mathrm{mg} / \mathrm{kg}$ bLF $(\mathrm{P}<0.05)$. The study indicated that addition of bLF improved the antioxidant function of piglets by up-regulation of mRNA levels and activities of certain antioxidant enzymes associated with free radicals metabolism.
\end{abstract}

KEY WORDS: lactoferrin, lipid peroxidation, antioxidant enzyme, piglet

\footnotetext{
* Supported by the National Basic Research Program of China (2004CB117506) and the Program for New Century Excellent Talents in University (NCET-04-0543)

${ }^{3}$ Corresponding authors : e-mail: yzwang@zju.edu.cn; e-mail: jxliu@zju.edu.cn
} 


\section{INTRODUCTION}

Free radical and other reactive oxygen species (ROS) are generated by all aerobic cells and are known to participate in a wide variety of deleterious reaction (Freeman and Crapo, 1982). In normal conditions aerobic organisms are protected against oxidative damage by a variety of antioxidant systems. The antioxidant system is divided into two groups as enzymatic and non-enzymatic. Enzymatic system include superoxide dismutase (SOD), glutathione peroxidase (GPx) and catalase (CAT) (Luo et al., 2004). Non-enzymatic antioxidant system, which consists of vitamin $\mathrm{E}$, vitamin $\mathrm{C}$, Se, $\beta$-carotene, lycopene and metal chelators such as transferrin and lactoferrin, has been shown to react with organic free radicals and protect biomembranes. There is often an interaction between different antioxidant defence systems (Moldeus, 1995). Iron can damage tissues by catalysed the conversion of superoxide and hydrogen peroxide to free radical species that attack cellular membranes, proteins and DNA (Gutterigde et al., 1982). Proteins sequester iron to reduce this threat.

Lactoferrin (LF) is a monomeric, cationic iron-binding glycoprotein that is present in milk, saliva and other exocrine secretions as well as in neutrophil granules (Natsuko et al., 2004). LF is a member of the transferrin family characterized by a carbonate-dependent, high affinity and reversible binding of two $\mathrm{Fe}^{3+}$ per molecule yielding a pink complex (Baker and Baker, 2004). LF has a number of biological functions. In addition to its antimicrobial activity, LF may function in intestinal iron uptake and regulation, immune response, growth factor activity, bone growth and antioxidant activity (Steijins and Van Hooijdonk, 2000; Cornish et al., 2004). LF rarely provides metal for the nutritional requirements of the cell except in the neonate. However, during an inflammatory state, a recognized function of lactoferrin is the transport of iron across cell membranes to be deposited in the ferritin of monocytes and macrophages (Van Snick et al., 1977). With the use of specific receptors, both these cells bind lactoferrin, and the glycoprotein is internalized. The binding site for lactoferrin is different from that for the transferrin receptor, and the two ligands do not cross-react with the receptors (Roiron et al., 1989). Lactoferrin is also thought to serve as an antioxidant since iron bound to the protein is unable to participate as a catalyst for the generation of the hydroxyl radical. The unique function attributed to the protection of LF from iron-induced lipid peroxidation (He and Furmanski, 1995). Lactoferrin inhibited oxidation in a concentration-dependent manner even at concentrations beyond its capacity to bind iron at its two highly affinity binding sites (SatueGracia et al., 2000). The antioxidant activity of bLF has been demonstrated in different biological and chemical environments. Bovine LF has been reported to lower lipid peroxidation by decreasing the conversion of $\mathrm{H}_{2} \mathrm{O}_{2}$ to $\mathrm{OH}$ by the 
Fenton reaction by sequestering iron (Shinmoto et al., 1992). Supplementation of lactoferrin in the diet of preterm infants also attenuated iron-induced oxidation products (Reghuveer et al., 2002). The chemopreventive potential of bLF may be attributed to its antioxidant properties. In the buccal pouch, lactoferrin reversed the susceptibility to lipid peroxidation and simultaneously increased the GSH/ GSSG ratio and GPx activity (Chandra Mohan et al., 2006).

A study demonstrated that over than $60 \%$ of administered bLF survives passage through the adult human stomach and enters the small intestine in an intact form (Troost et al., 2001). Some parts of ingested LF are likely to be not fully digested and to be present in the lower gastrointestinal tract. Orally administered LF exhibits several beneficial effects at sites other than the digestive tract. In the case of infants or adults with injury in the intestine, it is possible that ingested LF enters the blood circulation and acts systemically. Based on the large body of accumulated evidence, it is rational to consider that oral bLF or its digested products acts initially on the intestinal immune system and then augments the protective immunity systemically (Teraguchi et al., 2004).

Up to now, the effect of dietary bovine lactoferrin on antioxidant systems of piglets has not been reported. The current study was conducted to determine the effect of dietary bovine lactoferrin on lipid perioxidation and the activities and mRNA levels of antioxidant enzymes of piglets, and investigate possibilities of using exogenous antioxidants in strengthening endogenous antioxidant defense.

\section{MATERIAL AND METHODS}

\section{Drugs and chemicals}

Lactoferrin (concentration of Fe $1.54 \mu \mathrm{g} \mathrm{kg}^{-1}$ ) used in the current study with purity of $92.2 \%$ determined by high-performance liquid chromatography (HPLC) analysis was isolated from bovine colostrums and purchased from Tatua Co-operative Dairy Company Ltd. (Tatuanui, Morrinsville, New Zealand). Analysis by HPLC involved the use of an LC10 low-pressure gradient system (Shimadzu, Tokyo, Japan), a C4 column (Asahipak C4P-50 4D) and UV detection at $280 \mathrm{~nm}$ as described previously (Abe et al., 1991). Assay kits for protein, MDA, CuZnSOD, GPx, CAT and TAOC were obtained from Nanjing Jiancheng Bioengineering Institute.

\section{Animals and experimental design}

This experiment was approved by the Institutional Animal Care and Use Committee at Zhejiang University and was conducted in accordance with the 
National Institutes of Health guidelines for the care and use of experimental animals. The feeding trial was carried out in the Swine Research and Teaching Farm at Zhejiang University. Duroc $\times$ Landrace $\times$ Yorkshire female piglets $(n=120)$, 35 days of age and weighing $9.70 \pm 0.71 \mathrm{~kg}$, were randomly assigned to three treatments. The piglets had been weaned at 28 days after birth. Each of these groups consisted of four replications (i.e. pens) with ten pigs per replicate. The treatments received the same basal diet and supplemented with $0,1250 \mathrm{mg} / \mathrm{kg}$ $\mathrm{bLF}$, or $2500 \mathrm{mg} / \mathrm{kg} \mathrm{bLF}$, respectively. Diets were formulated to meet or exceed requirements for all nutrients. No antibiotic was included in diets (Table 1).

Table 1. Composition of experimental diets, as-fed basis

\begin{tabular}{lclc}
\hline Ingredients, \% & \multicolumn{2}{c}{ Analysed content, \% } \\
\hline Maize & 57 & Dry matter & 87.2 \\
Soyabean meal, $480 \mathrm{~g} \mathrm{CP} / \mathrm{kg}$ & 23 & Crude protein & 19.5 \\
Fish meal & 5 & Lysine & 1.5 \\
Wheat middlings & 3 & Methionine & 0.51 \\
Yeast & 2 & Threonine & 0.87 \\
Glucose & 3 & Ether extract & 3 \\
Pig prestarter & 3 & Crude fibre & 2.8 \\
Dicalcium phosphate & 1.2 & Ash & 3 \\
Limestone & 0.7 & Calcium & 0.81 \\
Sodium chloride & 0.3 & Total phosphorus & 0.66 \\
L-lysine HCl, 98 & 0.53 & Iron, mg/kg & 387.9 \\
DL-methionine & 0.15 & & \\
L-threonine & 0.12 & & \\
Vitamin-mineral premix ${ }^{1}$ & 1 & & \\
Calculated content DE, MJ/kg & 13.86 & & \\
\hline
\end{tabular}

${ }^{1}$ the vitamin-mineral premix provided, per kg feed, IU: vit. A 2200; vit. $\mathrm{D}_{3} 220$; mg: vit. E 16; vit. $\mathrm{K}_{3} 0.50$; vit. $\mathrm{B}_{1} 1.50$; vit. $\mathrm{B}_{2} 4.00$; vit. $\mathrm{B}_{6} 2.0$; vit. $\mathrm{B}_{12} 0.020$; niacin 20; D-pantothenic acid 12.00; biotin 0.08; folic acid 0.30; Fe 210; Cu 190; Mn 5; Zn 251mg; I 0.50; Se 0.34

The treatment diets (1250 and $2500 \mathrm{mg} / \mathrm{kg}$ bLF) were prepared by following processes. Intitially, the calculated amounts of bLF were carefully premixed with small portions of maize starch, and these premixes were then finally mixed into the feed previously supplemented with the recommended levels of all other nutrients. The feeding trial lasted for 30 days after seven days of adaptation period. All pigs were housed in an open-front pig barn with concrete floor and the size of the pens used was $350 \times 350 \mathrm{~cm}$. A dry $/$ wet feeders with two waterers was allocated in each pen for pigs. During the 30-day feeding trial, all pigs were given ad libitum access to feed and water. Feed consumption per pen was recorded daily, and pig weight was measured at 15-day intervals. Each day, feed refusals per pen were measured and subtracted from the total feed intake. 


\section{Sample collection and assay}

Sampling procedure. At the end of the feeding trial, twelve female piglets with four animals each treatment (one animal each pen) were randomly selected based on similar body weight for sampling. The pigs were fasted $12 \mathrm{~h}$ and euthanized by bleeding after intramuscular injection of sodium pentobarbital solution before slaughter. Blood samples ( $10 \mathrm{ml}$ per pig) were drawn in collection tubes by venipuncture of the anterior vena cava of pigs at approximately 8.00 a.m. before slaughter, then centrifuged at $1000 \times \mathrm{g}$ at $4^{\circ} \mathrm{C}$ for $10 \mathrm{~min}$, serum was separated and packed in Eppendorf tubes respectively. Liver samples for antioxidant enzymes activity and mRNA levels, TAOC and MDA assays were collected from each animal immediately after postmortem and packed in plastic bags. All samples were frozen by immersion in liquid $\mathrm{N}_{2}$ and stored at $-70^{\circ} \mathrm{C}$ until needed for analysis.

GPx, CuZnSOD, CAT, MDA and TAOC assay. CuZnSOD activity was analysed by monitoring the inhibition of the reduction of nitro blue tetrazolium by the sample at $560 \mathrm{~nm}$ (Winterbourn et al., 1975); GPx activity was detected with 55'-dithiobis-p-nitrobenzoic acid (Hafemen, 1974); CAT activity was determined using the method of Aebi (1984) in which the initial rate of hydrogen peroxide decomposition is determined. Samples were evaluated by the spectrophotometric method based on the reaction between MDA and thiobarbutiric acid (TBA). 1,1,3,3, Tetraethoxypropane was used as the standard solution $(10 \mathrm{nmol} / \mathrm{ml})$. Absorbance was measured at $532 \mathrm{~nm}$ using a spectrophotometer (Spectronic Instruments Inc., NY, USA). MDA (nmol/mgprot $)=[\mathrm{A}($ sample)-A(sampleblank)]/[A(standard)$\mathrm{A}($ standard blank $)] \times$ standard solution concentration/protein content $(\mathrm{mgprot} / \mathrm{ml})$ (Placer et al., 1966); the TAOC was measured by the method of ferric reducing/ antioxidant power assay (Benzie and Stain, 1996). For biochemical assays, liver tissues were homogenized in $0.1 \mathrm{~g} \mathrm{ml}^{-1}$ wet weight of ice-cold isotonic physiological saline and centrifuged at $5000 \times \mathrm{g}$ for $10 \mathrm{~min}$ at $4^{\circ} \mathrm{C}$. The supernatants and prepared serums were then subjected to the measurement of GPx, CuZnSOD, CAT, MDA and TAOC levels by spectrophotometric (spectrophotometer: Spectronic Instruments Inc., NY, USA) methods as described above. The activity of the enzyme was expressed as units per mg protein (for tissues) and units per $\mathrm{ml}$ (for serum).

\section{Determination of antioxidant enzymes $m R N A$ levels}

RNA isolation. Total RNA was isolated from liver by using TRIzol (Invitrogen Life Technologies, Carlsbad, CA) according to the manufacturer's manual. After pulverization and homogenization of the tissue, the homogenate was extracted 
with chloroform and then precipitated by isopropanol. The resulting pellets of total RNA were dissolved in ultra-pure water; the purity and concentration of total RNA were measured by a spectrophotometer at 260 and $280 \mathrm{~nm}$.

$R T-P C R$. RT-PCR was performed in a thermocycler (Gene Amp PCR system 9600, Perkin Elmer Cetus Instrument, USA). Two micrograms of RNA isolated from each sample was reverse transcribed using oligo (dT)15 primer (Promega, Madison, USA) and an RNA PCR kit (AMV) (Promega, Madison, USA), essentially according to the manufacture's protocol. The cDNA equivalent to 160 ng total RNA was subjected to PCR using Taq DNA Polymerase (Promega, Madison, USA) in a 50 volume containing $2.5 \mathrm{mM} \mathrm{Mg}{ }^{2+}, 0.4 \mu \mathrm{M}$ each sense and antisense primer. The PCR primer sets used are shown in Table 2. Primer

Table 2. Primer pairs used in the RT-PCR reactions

\begin{tabular}{|c|c|c|}
\hline Genes $^{1}$ & Primer sequences ${ }^{2}$ & $\begin{array}{l}\text { PCR product } \\
\text { bp }\end{array}$ \\
\hline GPx & $\begin{array}{l}\text { [S] 5'-CACAACGGTGCGGGACTA-3' [AS] 5'- } \\
\text { CATTGCGACACACTGGAGAC -3' }\end{array}$ & 326 \\
\hline $\mathrm{CuZnSOD}$ & $\begin{array}{l}\text { [S] 5'-CAGGTCCTCACTTCAATCC-3' [AS]5'- } \\
\text { CCAAACGACTTCCASCAT-3' }\end{array}$ & 255 \\
\hline CAT & $\begin{array}{l}\text { [S] 5' -CGAAGGCGAAGGTGTTTG - 3' [AS] 5' - } \\
\text { AGTGTGCGATCCATATCC -3' }\end{array}$ & 374 \\
\hline 18S rRNA & $\begin{array}{l}\text { [S] 5' - GCGGCTTTGGTGACTCTA - 3' [AS } \text { 5' }^{\prime} \\
\text { CTGCCTCCTTGGATGTG - 3' }\end{array}$ & 195 \\
\hline
\end{tabular}

${ }^{1} \mathrm{GPx}$ - glutathione perioxidase; CuZnSOD - copper-zinc-superoxide dismutase; CAT - catalase ${ }^{2} \mathrm{~S}$ - sense primer; AS - anti-sense primer

sequences for GPx, CuZnSOD, CAT and 18S rRNA housekeeping gene were designed by using the Primer Program of the Winsconsin Sequence Analysis Package (Genetics Computer Group, Inc.) based on known sequences deposited in Genebank. The optimum PCR reaction cycles and concentration of $\mathrm{Mg}^{2+}$ to give a linear amplification of each transcript were determined by a preliminary experiment (data not shown). The PCR profile for $18 \mathrm{~S}$ rRNA included denaturation at $94^{\circ} \mathrm{C}$ for 2 min, followed by 23 cycles of denaturation at $94^{\circ} \mathrm{C}$ for $50 \mathrm{sec}$, annealing at $52^{\circ} \mathrm{C}$ for $50 \mathrm{sec}$, and extension at $72^{\circ} \mathrm{C}$ for $1 \mathrm{~min}$, and a final extension at $72^{\circ} \mathrm{C}$ for $10 \mathrm{~min}$. The PCR profile for GPx, CAT and CuZnSOD was similar to 18S rRNA except cycles of 29.

\section{Data analysis}

Electrophoresis band intensities of the PCR products were quantified using Image Master VDS software (Amersham Pharmacia Biotech, Uppsala, Sweden). Mean antioxidant enzymes mRNA levels normalized against 18S rRNA levels from 
liver tissue of piglets from each treatment were presented in absolute integrated density. All analysis were performed in duplicate. The data were analysed by ANOVA using the general linear model procedure of SAS (SAS Inst. Inc., Cary, NC). Differences between treatment means at the $5 \%$ level were determined using the least significant different test.

\section{RESULTS}

\section{Lipid peroxidation and antioxidant defenses}

The determined results of MDA, TAOC, GPx, CuZnSOD and CAT levels in serum and liver of piglets are shown in Tables 3 and 4, respectively. The dietary

Table 3. Effect of bovine lactoferrin on antioxidant indexes in serum of piglets ${ }^{1}$

\begin{tabular}{lccc}
\hline \multirow{2}{*}{ Item $^{2}$} & \multicolumn{3}{c}{ Bovine lactoferrin, $\mathrm{mg} / \mathrm{kg}$} \\
\cline { 2 - 4 } & control $(0)$ & 1250 & 2500 \\
\hline MDA, nmol/ml & $4.14 \pm 0.14^{\mathrm{a}}$ & $3.30 \pm 0.14^{\mathrm{b}}$ & $2.63 \pm 0.13^{\mathrm{c}}$ \\
TAOC,U/ml & $2.84 \pm 0.17^{\mathrm{c}}$ & $3.90 \pm 0.40^{\mathrm{b}}$ & $6.81 \pm 0.38^{\mathrm{a}}$ \\
$\mathrm{CuZnSOD}, \mathrm{U} / \mathrm{ml}$ & $34.48 \pm 3.81^{\mathrm{c}}$ & $59.51 \pm 4.27^{\mathrm{b}}$ & $69.08 \pm 5.69^{\mathrm{a}}$ \\
$\mathrm{GPx}, \mathrm{U} / \mathrm{ml}$ & $472.03 \pm 34.92^{\mathrm{c}}$ & $856.95 \pm 63.51^{\mathrm{b}}$ & $1556.65 \pm 123.86^{\mathrm{a}}$ \\
$\mathrm{CAT}, \mathrm{U} / \mathrm{ml}$ & $12.54 \pm 1.79^{\mathrm{c}}$ & $16.84 \pm 1.56^{\mathrm{b}}$ & $21.30 \pm 1.93^{\mathrm{a}}$ \\
\hline
\end{tabular}

${ }^{1}$ values are presented as means $\pm \mathrm{SD} ; \mathrm{n}=4$ per treatment. Means within a row with different letters differ significantly $(\mathrm{P}<0.05)$

2 MDA - malondialdehyde; TAOC - total antioxidant capacity; GPx - glutathione perioxidase; CuZnSOD - copper-zinc-superoxide dismutase; CAT - catalase

Table 4. Effect of bovine lactoferrin on antioxidant indexes in liver of piglets ${ }^{1}$

\begin{tabular}{lrrr}
\hline \multirow{2}{*}{ Item $^{2}$} & \multicolumn{3}{c}{ Bovine lactoferrin, $\mathrm{mg} / \mathrm{kg}$} \\
\cline { 2 - 4 } & \multicolumn{1}{c}{ control $(0)$} & \multicolumn{1}{c}{2500} \\
\hline MDA, nmol/mgprot & $4.34 \pm 0.23^{\mathrm{a}}$ & $3.41 \pm 0.14^{\mathrm{b}}$ & $2.14 \pm 0.38^{\mathrm{c}}$ \\
TAOC,U/mgprot & $2.22 \pm 0.14^{\mathrm{b}}$ & $2.35 \pm 0.13^{\mathrm{b}}$ & $2.94 \pm 0.64^{\mathrm{a}}$ \\
CuZnSOD, U/mgprot & $60.95 \pm 6.31^{\mathrm{c}}$ & $65.01 \pm 7.65^{\mathrm{b}}$ & $71.24 \pm 6.54^{\mathrm{a}}$ \\
GPx, U/mgprot & $12.41 \pm 0.54^{\mathrm{c}}$ & $20.73 \pm 0.85^{\mathrm{b}}$ & $25.27 \pm 0.64^{\mathrm{a}}$ \\
CAT, U/mgprot & $40.91 \pm 4.37^{\mathrm{c}}$ & $43.51 \pm 4.69^{\mathrm{b}}$ & $52.56 \pm 5.65^{\mathrm{a}}$ \\
\hline
\end{tabular}

${ }^{1}$ values are presented as means $\pm \mathrm{SD} ; \mathrm{n}=4$ per treatment. Means within a row with different letters differ significantly $(\mathrm{P}<0.05)$

${ }^{2}$ MDA - malondialdehyde; TAOC - total antioxidant capacity; GPx - glutathione perioxidase; CuZnSOD - copper-zinc-superoxide dismutase; CAT - catalase

addition of $2500 \mathrm{mg} / \mathrm{kg}$ bLF significantly $(\mathrm{P}<0.05)$ increased the TAOC, GPx, $\mathrm{CuZnSOD}$ and CAT levels in serum and liver of piglets, and significantly decreased MDA levels in serum and liver of experimental piglets as compared with control. 
Similarly significant $(\mathrm{P}<0.05)$ increases in GPx, CuZnSOD and CAT activities and significantly $(\mathrm{P}<0.05)$ decreases in MDA were found in piglets fed the diet treated with $1250 \mathrm{mg} / \mathrm{kg}$ bLF as compared with control. Moreover, supplementation with $2500 \mathrm{mg} / \mathrm{kg}$ bLF was more effective than supplementation with $1250 \mathrm{mg} / \mathrm{kg}$ bLF in enhancing antioxidant function of piglets.

\section{Antioxidant enzymes GPx, CuZnSOD and CAT mRNA levels}

The effect of supplementation with 1250 or $2500 \mathrm{mg} / \mathrm{kg}$ bLF on antioxidant enzymes (GPx, CuZnSOD and CAT) mRNA expression in liver of piglets was investigated. The electrophoresis results of four piglets of each experimental groups are shown in Figure 1. Electrophoresis band intensities of PCR products

$\begin{array}{lll}1 & 2 & 3\end{array}$

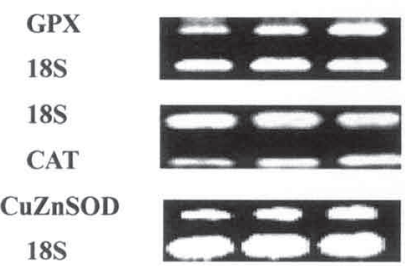

a $\begin{array}{lll}1 & 2 & 3\end{array}$
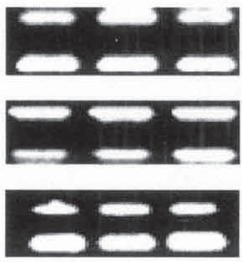

b
$1 \quad 2 \quad 3$

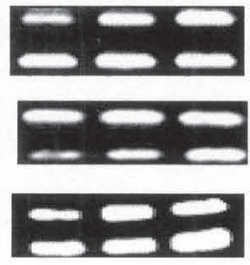

c $\begin{array}{lll}1 & 2 & 3\end{array}$
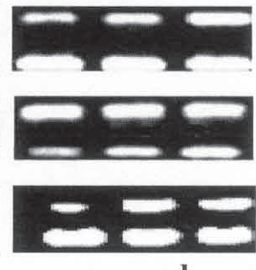

d

Figure 1. Effect of dietary bLF on antioxidant enzymes mRNA expression when piglets was analysed by RT-PCR. Amplified products obtained with mRNA after transcription were size-fractionated on a $1.0 \%$ agarose gel. The gel was stained with ethidium bromide, and PCR products were observed under UV light (Immage master VDS). Shown are used as an internal control. Lane $1=0 \mathrm{mg} / \mathrm{kg}$ bLF; lane $2=1250$ $\mathrm{mg} / \mathrm{kg} \mathrm{bLF}$ and Lane $3=2500 \mathrm{mg} / \mathrm{kg}$ bLF. Four repetitions are represented by a, b, c and d

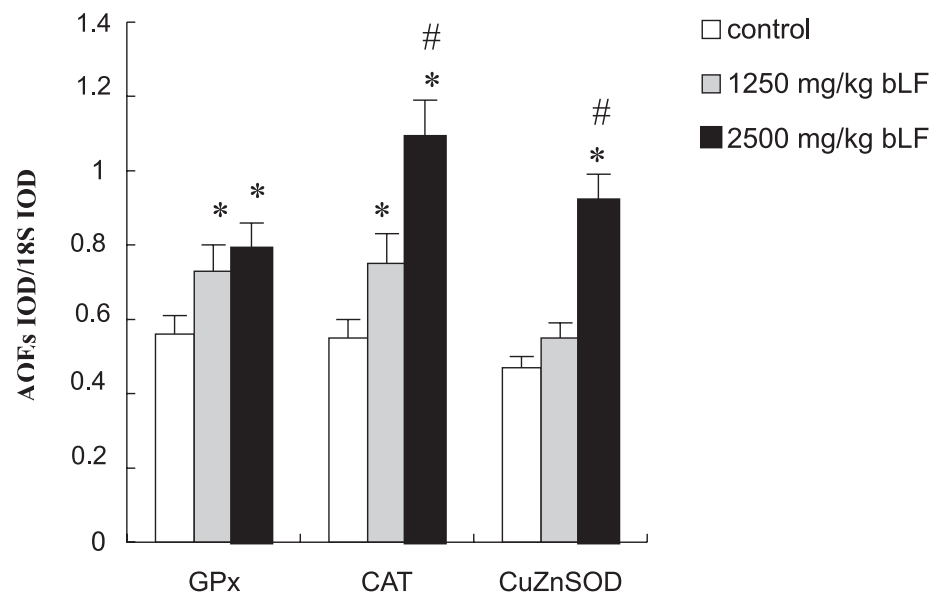

Figure 2. mRNA expression of GPx, CAT, CuZnSOD in liver of piglets fed diets supplemented with $0,1250 \mathrm{mg} / \mathrm{kg} \mathrm{bLF}$ and $2500 \mathrm{mg} / \mathrm{kg} \mathrm{bLF}$, respectively. Densitometric analysis of pig antioxidant enzymes (AOEs) were normalized to $18 \mathrm{~S}$ rRNA and were shown as AOEs IOD/18S rRNA IOD. Values were presented in mean $\pm \mathrm{SD}(\mathrm{n}=4)$. ${ }^{*} \mathrm{P}<0.05$ vs controls; ${ }^{*} \mathrm{P}<0.05 \mathrm{vs} 1250 \mathrm{mg} / \mathrm{kg}$ bLF 
were quantified and analysed for statistical difference. The current results (Figure 2) showed that supplementation with $2500 \mathrm{mg} / \mathrm{kg}$ bLF significantly $(\mathrm{P}<0.05)$ increased GPx, CuZnSOD and CAT mRNA levels by 41.07, 95.74 and $98.18 \%$ as compared with control. Feeding diet containing $1250 \mathrm{mg} / \mathrm{kg} \mathrm{bLF}$ significantly $(\mathrm{P}<0.05)$ increased GPx and CAT mRNA levels by 30.36 and $36.36 \%$ as compared with control. Moreover, $2500 \mathrm{mg} / \mathrm{kg}$ bLF was more effective than $1250 \mathrm{mg} / \mathrm{kg}$ bLF in enhancing CuZnSOD and CAT mRNA expression $(\mathrm{P}<0.05)$.

\section{DISCUSSION}

In our previous study, we investigated effect of lactoferrin on growth performance, intestinal morphology, and expression of PR-39 and protegrin-1 genes in weaned piglets (Wang et al, 2006), and exploited the silkworm, Bombyx mori, as host for the recombinant baculovirus harboring the porcine lactoferrin (PLF) gene to produce the recombinant PLF (rPLF) (Wang et al., 2005a). In addition, we evaluated the developmental gene expression of lactoferrin (LF) and the effect of supplementary iron on gene expression of LF in the mammary gland of mice, which demonstated that iron significantly increased LF mRNA on 1 and 25 of lactation (Wang et al, 2005b). In the present study, we studied the effect of dietary bovine lactoferrin on antioxidant systems of piglets. MDA is a main marker of endogenous lipid peroxidation and the activity levels of the antioxidant enzymes (GPx, CuZnSOD and CAT). In the current study, supplementation with $1250 \mathrm{mg} / \mathrm{kg}$ and $2500 \mathrm{mg} / \mathrm{kg}$ bLF both significantly decreased the MDA levels in serum and liver of piglets, which indicated that bLF could protect from lipid peroxidation of piglets. Antioxidant enzymes are considered to be a primary defense that prevents biological macromolecules from oxidative damage. In the present study, GPx, CuZnSOD and CAT activities in serum and liver substantially increased from piglets fed bLF treated diet. It is likely that the increase in the activity of GPx, CuZnSOD and CAT are the main factors of decrease in lipid peroxidation. In addition, the substantially higher levels of antioxidants in the liver suggest that tissue antioxidant requirement is dictated by metabolic rate. The role of liver for the storage of iron is basic (Bonkovsky, 1991). The liver has first-pass access to dietary nutrients and can readily take up an amount of circulating iron that exceeds the binding capacity of plasma transferrin. Hepatocytes have both transferrin and ferritin receptors as well as for haemoglobin, haptoglobin, and heme, and get iron from all these molecules, especially of ferritin coming from Kupfer cells (Bonkovsky, 1991). In this study, we also investigated the TAOC of the experimental piglets. The increase in TAOC of serum and liver from piglets fed the additional bLF diets suggested that increase in the non-enzymatic antioxidant defense probably contributed to protect from endogenous lipid peroxidation and oxidation.

Supplementation with bLF also induced mRNA expression of GPx, CuZnSOD and CAT in liver of in piglets. The enhanced activity of GPx, CuZnSOD and CAT 
and increased TAOC in the piglets can be very effective in scavenging the various types of oxygen free radicals and their products. So the inhibitory effect of bovine lactoferrin on lipid peroxidation might be, at least in part, attributed to its influence on the antioxidant enzymes and non-enzymatic system. In addition, it is possible that the effect of bLF on GPx, CuZnSOD and CAT activity was associated with its induction on gene expression of GPx, CuZnSOD and CAT. Iron is a component of some enzymes such as SOD and CAT (Mccord, 1998). The iron-sulphur cluster and iron-protoporphyrin (i.e. heme) are cofactors of these enzymes. The increase in mRNA levels of CuZnSOD and CAT in liver with the dietary bLF treatments may be ascribed to an induction of iron. On the other hand, the possible mechanism of action was related with dietary antioxidant such as Se and vitamin E, which may also accelerate gene expression of antioxidant enzymes.

Many researches have shown that lactoferrin possesses antioxidative properties (Rebelo et al., 1995; Satue-Gracia et al., 2000). In this study, the determined results demonstrated that dietary $2500 \mathrm{mg} / \mathrm{kg}$ bLF significantly increased activity and mRNA expression of antioxidant enzymes, TAOC, and reduced risks of lipid peroxidation of piglets. The possible mechanisms may be related to the physicochemical properties of lactoferrin. A study demonstrated that over than $60 \%$ of administered bLF survives passage through the adult human stomach and enters the small intestine in an intact form (Troost et al., 2001). These intact bLF and partially digested bLF peptides, which retain biological activities, may exert various physiological effects in the digestive tract. Orally administered LF exhibits several beneficial effects at sites other than the digestive tract (Wakabayashi et al., 2006). The detailed molecular mechanisms must be elucidated in future studies.

Iron has a well-documented ability to initiate oxidative stress via the generation of cytotoxic hydroxyl radicals through the Fenton reaction (Fillebeen et al., 1999). The living organisms are protected from iron-mediated oxidative damage by two mechanisms. To prevent this oxidative attack, proteins sequester iron. Iron ions circulate bound to plasma transferrin, and accumalate within cells in the form of ferritin (Harrison and Arosio, 1996). To prevent an excess of storage, the absorption of iron is finely regulated. Lactoferrin has long been recognized as a member of the transferrin family of proteins and an important regulator of the levels of free iron in the body fluid of mammals (Baker and Baker, 2004). Lactoferrin may have an important role by binding pro-oxidative iron ions (Lindmark-Mansson and Akesson, 2000). Lactoferrin, not depending on the source of its obtaining, is an efficient iron chelator and decreases intensity of peroxidative processes (Sandomirsky et al., 2003). Its ability to bind ferric iron can be well understood in terms of its three dimemsional (3D) structure. Lactoferrin contains two high-affinity ferric iron binding sites and is thought to function as host defense in part by sequestering iron (Weinberg, 1993). Lactoferrin is thought to serve as an antioxidant since iron bound to the protein is unable to participate as a catalyst for the generation of the hydtoxyl radical (Britigan et al., 1986). By its function as an iron chelator (Shinmoto et al., 1992), LF might also be considred as an oxidative stress 
detoxificant. On the other hand, the possible mechanism of action was that dietary bLF accelerated absorption of iron. Lactoferrin inhibited oxidation in a concentrationdependent manner even at concentrations beyond its capacity to bind iron at its two highly affinity binding sites (Satue-Gracia et al., 2000). The current determined results also demonstrated that the additional $2500 \mathrm{mg} / \mathrm{kg}$ bLF to diet had better effect than corresponding additional $1250 \mathrm{mg} / \mathrm{kg}$ bLF in strengthening endogenous antioxidant defence systems and reducing lipid peroxidation.

\section{CONCLUSIONS}

This study showed that dietary bovine lactoferrin decreased lipid oxidation, enhanced antioxidant enzymes activity and mRNA levels. We would speculated that exogenous bovine lactoferrin could be used in strengthening the endogenous antioxidant defence systems and thereby reduced the risks of lipid peroxidation. By capturing the iron in some organs or tissues, LF may act as a natural scavenger of reactive oxygen species (ROS). Since the effects of exogenous lactoferrin on endogenous antioxidant systems in piglets has received little attention. The exact mechanism needs further investigation. Future research will be necessary to elucidate possible mechanisms of action of lactoferrin for protection against oxidative damage so that additional strategies may be developed for strenghthening endogenous antioxidant defence.

\section{REFERENCES}

Abe H., Saito H., Miyakawa H., Tamura Y., Shimamura S., Nagao E., 1991. Heat stability of bovine lactoferrin at acidic pH. J. Dairy Sci. 74, 65-71

Aebi H., 1984. Catalase in vitro. Methods Enzymol. 105, 121-126

Baker H.M., Baker E.N., 2004. Lactoferrin and iron: structural and dynamic aspects of binding and release. Biometals 17, 209-216

Benzie I.E.F., Stain J.J., 1996. The ferric reducing ability of plasma (FRAP) as a measure of "antioxidant power", the FRAP assay. Anal Biochem. 239, 70-76

Bonkovsky H.L., 1991. Iron and the liver. Amer. J. Med. Sci. 301, 32-43

Britigan B.E., Rosen G.M., Thompson B.Y., Chai Y., Cohen M.S., 1986. Stimulated neutrophils limit iron-catalyzed hydroxyl radical formation as defected by spin trapping techniques. J. Biol. Chem. 261, 17026-17039

Chandra Mohan K.V.P., Ramasamy K., Duvuru P., Siddavaram N., 2006 Modulation of xenobioticmetabolizing enzymes and redox during chemoprevention of hamster buccal carcinogenesis by bovine lactoferrin. Nutrition 22, 940-946

Cornish J., Callon K.E., Naot D., Palmano K.P., Banovic T., Bava U., 2004. Lactoferrin is a potent regulator of bone cell activity and increases bone formation in vivo. Endocrinolology 145, 4366-4374

Fillebeen C., Mitchell V., Dexter D., Benaissa M., Beauvillain J.-C., Spik G., Pierce A., 1999. Lactoferrin is synthesized by mouse brain tissue and its expression is enhanced after MPTP treatment. Mol. Brain Res. 72, 183-194

Freeman B.A., Crapo J.D., 1982. Biology of disease: free radicals and tissue injury. Lab. Invest. 47, 412-426

Gutteridge J.M.C., Rowley D.A., Halliwell B., 1982. Superoxide-dependent formation of hydroxyl radical and lipid peroxidation in the presence of iron salt: detection of catalytic iron and antioxidant activity in extracellular fluids. J. Biochem. 206, 605-609 
Hafemen D.G., 1974. Effect of dietary selenium on erythrocyte and liver glutathione peroxidase in the rats. J. Nutr. 104, 580-587

Harrison P.M., Arosio P., 1996. The ferritins, molecular properties, iron storage function, and cellular regulation. Biochem. Biophys. Acta 1275, 161-203

He J., Furmanski P., 1995. Sequence specificity and transcriptional activation in the binding of lactoferrin to DNA. Nature 373, 721-724

Lindmark-Mansson H., Akesson B., 2000. Antioxidative factors in milk. Brit. J. Nutr. 84, Suppl. 1, $103-110$

Luo Y.M., Zhen Q., Zhen H., Zhang X.M., Ding D., Fu J.H., Zhang W.D., Chen J., 2004. Astragaloside IV protects against ischemic brain injury in a murine model of transient focal ischemia. Neurosci. Lett. 363, 218-223

Mccord J.M., 1998. Iron free radicals, and oxidative injury. Hematology 35, 5-12

Moldeus P., 1995. Defence mechanisms in free radical induced toxicities. Toxicol. Lett. 78, Suppl. $1,1-88$

Natsuko T., Hiroyuki W., Hiroko I., Koji Y., Susumu T., Yoshitaka T., Hideyo Y., Shigeru A., 2004. Effect of orally administered bovine lactoferrin on the immune response in the oral candidiasis murine model. J. Med. Microbiol. 54, 495-500

Placer Z.A., Cushman L.L., Johnson B.C., 1966. Estimation of production of lipid peroxidation, malindialdehyde in biochemical system. Anal. Biochem. 16, 359-367

Raghuveer T.S., McGuire E.M., Martin S.M., Balansky R.M., Noonan D., Albini A., 2002. Lactoferrin in the preterm infants diet attenuated iron - induced oxidation products. Pediat. Res. 52, 964-972

Rebelo I., Carvalho-Guerra F., Pereira-Leite L., Quintanilha A., 1995. Lactoferrin as a sensitive blood marker of neutrophil activation in normal pregnancies. Eur. J. Obstet. Gyn. Reprod. Biol. 62, 189-194

Roiron D., Amouric M., Marvaldi J., Flgarella C., 1989. Lactoferrin-binding sites at the surface of HT29-D4 cells. Eur. J. Biochem. 186, 367-373

Sandomirsky B.P., Galchemko S.E., Galchenko K.S., 2003. Antioxidative properties of lactoferrin from bovine colostrums before and after its lyophilization. Cryo-lett. 24, 275-280

Satue-Gracia M.T., Frankel E.N., Rangavajhyala N., German J.B., 2000. Lactoferrin in infant formulas: effect on oxidation. J. Agr. Food Chem. 48, 4984-4990

Shinmoto H., Dosako S., Nakajima I., 1992. Antioxidant activity of bovine lactoferrin on iron/ ascorbate induced lipid peroxidation. Biosci. Biochnol. Biochem. 56, 2079-2080

Steijns J.M., Van Hooijdonk A.C.M., 2000. Occurrence, structure, biochemical properties and technological characteristics of lactoferrin. Brit. J. Nutr. 84, Suppl. 1, S11-S17

Teraguchi S., Wakabayashi H., Kuwata H., Yamauchi K., Tamura Y., 2004. Protection agaist infections by oral lactoferrin: Evaluation in animal models. Biometals 17, 231-234

Troost F.J., Straub P.W., Brummer R.J.M., 2001 Gastric digestion of bovine lactoferrin in vivo in adults. J. Nutr. 131, 2101-2104

Van Snick J.L., Markowetz B., Masson P.L., 1977. The ingestion and digestion of human lactoferrin by mouse peritoneal macrophages and the transfer of its iron into ferritin. J. Exp. Med. 146, 817-827

Wakabayashi H., Yamauchi K., Takase M., 2006. Lactoferrin research, technology and applications. Inter. J. Dairy (in press)

Wang Y.Z., Shan T. Z., Xu Z.R., Liu J.X., Feng J., 2006. Effect of lactoferrin on the growth performance, intestinal morphology, and expression of PR-39 and protegrin-1 genes in weaned piglets. J. Anim. Sci. 84, 2636-2641

Wang Y.Z., Tu Y.J., Han F.F., Wang J.H., 2005b. Developmental gene expression of lactoferrin and effect of dietary iron on gene regulation of lactoferrin in the mice mammary gland. J. Dairy Sci. 88, 2065-2071

Wang Y.Z., Wu X.F., Liu G.F, Cao C.P., Huang H.Q., Xu Z.R. Liu J.X., 2005a. Expression of porcine lactoferrin by using recombinant baculovirus in silkworm, Bombyx mori $\mathrm{L}$, and its purification and characterization. Appl. Microbiol. Biotechnol. 69, 385-389

Weinberg E.D., 1993. The development of awareness of iron-withholding defense. Perspect. Biol. Med. 36, 215-223

Winterbourn C.C., Hawkins R.E., Brain M., Carrell R., 1975. The estimation of red cell superoxide dismutase activity. J. Lab. Clin. Med. 85, 337-341 